\title{
ORAL TRADITION AND THE HISTORY OF ENGLISH ALLITERATIVE VERSE
}

\author{
Rafael J. Pascual*
}

\section{Introduction}

Middle English verse of the so-called Alliterative Revival evinces a pattern of alliteration across the line and a series of rhythmical configurations within the half-line that are reminiscent of those of classical Old English verse. It also possesses a rich inventory of poetic lexis that is genetically derived from the specialized diction of Old English poetry. As a result, scholars of a philological bent reasonably credit the hypothesis that fourteenth-century alliterative verse is not an artificial resurrection of long dead practices, but a natural development of a living oral tradition of versification that reaches back to the Anglo-Saxon period and beyond. ${ }^{1}$ Because of its inconsistent use of alliteration, looseness of rhythm, and dearth of poetic vocabulary, early Middle English poetry of the twelfth and thirteenth centuries strikes these scholars as an unconvincing link between Old English and later Middle English alliterative poetry (see, e.g., Fulk 2012: 132). Consequently, the oral tradition of alliterative verse is assumed to have flourished without documentation approximately two hundred and fifty years (from Durham, composed sometime between 1104 and 1109, to William of Palerne, c. 1350).

In spite of the evidence in support of this theory, the notion that an oral poetic tradition existed in England for more than two centuries without leaving a textual trace has met widespread resistance among some literary scholars, who generally prefer to endorse Norman Blake's alternative explanation. In an influential essay (1969), he argued that the verse of the Alliterative Revival is the result of the poets' tightening efforts on the loose style of alliterative composition that they inherited from Lazamon and his early Middle English contemporaries. Aware that such

\footnotetext{
* University of Alicante, Spain. Email: rjpascual@ua.es.

${ }^{1}$ See, for example, Oakden 1930-1935, II: 113-141; chapters 2 and 3 in Everett 1955; Fulk 2004 ; Russom 2004.
} 
a style is not a likely descendant of the strict practices of classical Old English poets, Blake also contended that the Old English poetic tradition died out with the Norman Conquest, and that the early Middle English mode of composition was rather derived from Ælfric of Eynsham's rhythmical writings. ${ }^{2}$ Blake’s theory satisfies the literary scholars' desire for early Middle English textual antecedents to the Alliterative Revival, but it does not furnish a satisfactory account for the striking similarities exclusively shared by Old English and late Middle English alliterative verse. Indeed, it is difficult to concur with Blake that fourteenth-century poets set their hands on Lazamon's style and came up with a new form that happens to look like the outgrowth of the Old English poetic tradition. Therefore, the hypothesis that verse of the Alliterative Revival ultimately derives from Old English poetry through a continuous process of oral transmission remains the superior account, and Eric Weiskott is to be commended for recapitulating in his recent monograph (2016) one of the soundest arguments in its favor. As he persuasively argues, the only plausible explanation for the phonological structure of late Middle English poeticisms like hathel, burn, renk, freke, and gome, among others, is that they were continuously transmitted by word of mouth from one generation of poets to the next between the Anglo-Saxon and the late Middle English periods. ${ }^{3}$

Like the philologists, Weiskott finds the lexical argument in support of the survival of classical Old English poetry too forceful to be ignored. Unfortunately, however, he is also unwilling to abandon Blake and his followers' belief that a literary history ought not to rely on the

\footnotetext{
${ }^{2}$ For a characterization of Ælfric's style as prose (and, hence, as an implausible source for early Middle English poetry), see Pascual 2014.

${ }^{3}$ Cf. Old English hrelep, cððele, beorn, rinc, freca, guma. As the editors of the standard edition of Sir Gawain and the Green Knight put it in regard to the semantic field of 'man':

the well-known group of synonyms for 'man' which supplement the ordinary mon, knizt, noble, prince — burn, freke, gome, hathel, lede, renk, schalk, segge, wyze. Of these renk, though it may be directly from ON., has a close cognate in OE. rinc; all the others descend directly from OE. (hathel evidently a blend of hrelep and cepele), and all the OE. words are found either exclusively or predominantly in poetry. (Tolkien \& Gordon 1967: 139)
} 
assumption of an undocumented oral tradition. Thus, throughout five of the six chapters of his book, Weiskott strives to construct a metrical history of alliterative verse that incorporates early Middle English poetry as the intermediate evolutionary stage between classical Old English and late Middle English verse, despite the existence of compelling evidence to the contrary. The inevitable result of this unworkable endeavor is an argument so saturated with anti-empirical claims and inconsistencies that it will disconcert general readers and provoke the outright rejection of specialists. One such inconsistency has already been noted. Weiskott advocates the survival of the Old English poetic tradition on account of the high incidence of Old English-derived poetic lexis in late Middle English verse, but he simultaneously ignores the relative scarcity of such lexis from early Middle English poems in order to integrate them into his historical account. ${ }^{4}$ This inconsistent treatment of the evidence is a clear indication of the author's strong bias against the philological theory of oral transmission—a bias to which he gives explicit articulation. Confronted with the absence of textual evidence for the composition of early Middle English poetry between 1240 and 1350, he admits that "the lack of firm documentary evidence for alliterative poetry in a 90-year window is inconvenient," (2016: 103) and explains it away as the consequence of a hypothetical and exceptionally substantial loss of manuscripts that took place during this brief period of time. This bias against the theory of oral transmission has led Weiskott to propose an alternative theory that contains a number of problematic aspects, the most significant of which are addressed in the present essay.

\section{Two Competing Theories of English Alliterative Verse}

Arguably, the clearest sign of the alienation of early Middle English poetry from the alliterative tradition is its inconsistent use of alliteration. In poetry of the Anglo-Saxon period and the

\footnotetext{
${ }^{4}$ On the relative scarcity of Old English-derived poetic diction in early Middle English poetry, see Fulk 2012: 132.
} 
Alliterative Revival, alliteration is the compulsory linking device between the two halves of the line, and its distribution within each half is rule-governed. ${ }^{5}$ The lines of early Middle English verse, on the other hand, can be linked indistinctly by alliteration or rhyme, or even feature no formal linking at all. Moreover, when alliteration is used, it may fall on any stressed syllable within the verse. What does the inconsistent use of alliteration in early Middle English poetry tell us about its relation to the history of the alliterative tradition? The answer to this question depends, of course, on how essential the role of alliteration is to that tradition. Scholars of alliterative verse have generally been aware that alliteration furnishes the basis for the line's bipartite structure in Old and late Middle English, which is why they find an unattested body of oral poems to be a likelier source for the Alliterative Revival than the surviving early Middle English verse, which is a small corpus in any case. Simply put, they deem it more probable that poets continued to rely on a regular pattern of alliteration for binding their verses together between the beginning of the twelfth and the middle of the fourteenth century (even if no textual records of their compositions survive) than that alliterative poetry got rid of one of its structural features at the end of the Anglo-Saxon period only to recover it two hundred and fifty years later.

Weiskott takes a different stance on the status of alliteration. He maintains that virtually the entire tradition of scholarship on alliterative verse is wrong about the importance it has accorded this feature. From his point of view, alliteration is merely a trinket, an ornamental characteristic alien to the structure of the verse whose significance has been exaggerated by past generations of scholars. He therefore proposes a radically new definition of alliterative verse, which constitutes the foundation of his entire metrical history: ${ }^{6}$

\footnotetext{
${ }^{5}$ For a compelling demonstration that the classical corpus of late Middle English alliterative verse evinces virtually the same pattern of alliteration across the line as Old English poetry, see Duggan 1986.

${ }^{6}$ For his definition of alliterative verse, Weiskott claims to be expanding on the unpublished work of Nicolay Yakovlev (2008).
} 
To capture all and only alliterative poems, it is sufficient to state that the alliterative meter is an English inductive meter in two half-lines. Throughout this study I treat alliterative meter without reference to alliteration, which I regard as an ornament, not a metrical entity. [note] In keeping with the practice of past scholars, I reserve the term 'alliterative' to refer to the alliterative meter as defined herein, though inductive scansion and half-line structure, not alliteration, are its critical features. (2006: 5)

Thus, the bipartite structure of the lines of a poetic work and their inductive scansion (a feature that I will discuss below) are, according to Weiskott, the key factors that determine its genetic affiliation to the alliterative tradition. From his point of view, the excessive emphasis given to alliteration has made early Middle English poetry look more idiosyncratic than it really is. If inductive scansion and half-line structure are reinterpreted as the two most important characteristics of alliterative verse, and if alliteration is reanalyzed as a dispensable ornament, then early Middle English poetry emerges as the transitional stage between Old and late Middle English. $^{7}$

Is this new definition of alliterative verse, with its demotion of alliteration, empirically justified? Or is it calculated to accommodate Lazamon and his early Middle English contemporaries? The correct alternative will be obvious to specialists, who are surely cognizant of the indispensable role of alliteration in binding together the two halves of the long line. The binding function of alliteration is especially apparent in Old English poetry. Because its syntactic units tend to be larger than its metrical lines, alliteration frequently is the only guidance as to whether a

\footnotetext{
${ }^{7}$ Weiskott also contends that English alliterative poets of the three historical periods share a common interest in the distant past. In order to substantiate this claim, he develops a meticulous typology of prologues to Old and Middle English poetry, which constitutes, by itself, a valuable contribution to the field of medieval English literature. Nonetheless, this typology does not seem to support the author's point that fondness for the distant past is a permanent feature of alliterative verse throughout its history. If it were correct, one should expect the 'olde-tyme' prologue to occur more often in poems classified as alliterative, but the opposite is the case, as he concedes. In fact, alliterative poems as traditional as Guthlac $A$ and The Battle of Maldon take a deep interest in the most recent past, and so they furnish strong counterevidence to Weiskott's interpretation, which appears to have been motivated merely by his desire to include Lazamon, a historian, in the alliterative tradition.
} 
given half-line is an on- or an off-verse. This point can be readily illustrated with a short excerpt from Beowulf:

\author{
Ic் pæs wine Denigea, \\ frēan Scildinga frīnan wille, \\ bēaga bryttan, swā pū bēna eart, \\ pēoden mǣrne ymb pīnne sīð. (350b-353)
}

[About that I will ask the friend of the Danes, lord of the Scyldings, the bestower of rings, as you are requesting, the renowned lord about your mission. $]^{8}$

Without the aid of alliteration, it would have been impossible for both members of the audience and modern editors to analyze linguistic sequences like frēan Scildinga, bēaga bryttan, or pēoden mērne as on-verses. If we take seriously the claim that alliteration is merely ornamental, the verses could be arranged differently without affecting the sense of the passage:

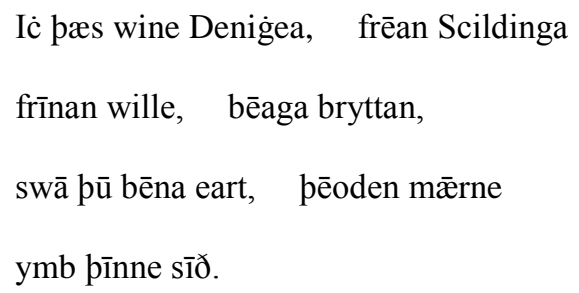

It can thus be seen that the editors' motivation for arranging the verses as pairs of half-lines is the alliterative scheme, which gives reality to the line as a metrical entity in Old English poetry. Weiskott's interpretation of the line's bipartite structure as an essential characteristic of alliterative verse is therefore incompatible with his claim that alliteration is an ornamental, non-structural property. This logical inconsistency should suffice to demonstrate the tendentious character of Weiskott's argumentation. An examination of the feature that he defines as 'inductive scansion' is nonetheless worth pursuing in the remainder of this essay, not only because it will shed new light on the less well-known role of alliteration in structuring the rhythm of the half-lines, but also

\footnotetext{
${ }^{8}$ Beowulf is cited from Fulk, Bjork, \& Niles 2008. The translation is from Fulk 2010.
} 
because it will corroborate the philologists' views about oral tradition and the history of English alliterative verse.

Weiskott's theory of metrical evolution is predicated upon the notion that alliteration is less essential to alliterative poetry than its inductive scansion. 'Inductive' is a term that he borrows from the work of Lynn Cole (2007). Both of them find the terms 'deductive' and 'inductive' useful to capture a fundamental difference between alliterative verse and other metrical traditions. In Weiskott's words:

Very deductive meters, such as tetrameter, consist of the concatenation of perceptually similar metrical units (feet, syllables, etc.). As a result, they have a predictable beat (hence 'deductive’). Very inductive meters, such as the alliterative long line, consist of the juxtaposition of perceptually dissimilar metrical units (halflines, dips, etc.: see below). As a result, they have no predictable beat: the pattern of each metrical unit must be discovered on a case-by-case basis through the application of specialized principles for the assignment of stress (hence ‘inductive’). (2006: 5)

Certainly, each half of the long line in Old, early Middle, and late Middle English poetry was able to display one of a variable number of rhythms, and there was no way for members of the audience to predict it before recitation. Weiskott interprets this rhythmical variability and its concomitant scansional unpredictability as essential characteristics of alliterative versification, which he therefore defines as a meter whose "constituent units do not alternate in a perceptually regular pattern" (2006: 10). Or, as Cole puts it, "the pattern of each line is a surprise" (2007: 21). This interpretation, however, conceals an important difference between Old and late Middle English poetry, on the one hand, and early Middle English verse, on the other.

The source of the rhythmical variability of Old English poetry is the connection that exists between metrical ictus and prosodic stress. Metrical ictus does not occupy a stable and hence predictable location within the verse, but it rather falls wherever a naturally stressed syllable 
happens to be. This equation of ictus with prosodic stress would effectively efface the difference between meter and natural speech were it not for the superimposition of a regularizing pattern of alliteration upon the linguistic material of the poetry. The regularizing function of alliteration becomes apparent upon observation of the distribution of so-called protracted drops. As Edwin Duncan demonstrated in an important essay (1993), if a metrical position contains several unstressed syllables, it always occurs either before the first lift of type B and C verses or after the first lift of a type A, in which case its second lift must alliterate. ${ }^{9}$ The implication of Duncan's findings is that a verse is allowed to contain several unstressed syllables only if they are put together immediately before an alliterating lift. The attracting effect that alliteration exerts upon unstressed syllables imposes constraints on the rhythmical possibilities of the verse. Thus, linguistic sequences containing two different series of unstressed syllables, which can be found in prose, are excluded from the poetry. Moreover, because the last lift of the line is prohibited from alliteration, type A verses with a protracted drop can occur only in the first half-line. As can be seen, the metrical configuration of the verses and their distribution is, to a large extent, determined by the demands of alliteration.

In light of these observations, Cole's claim that in alliterative verse "the pattern of each line is a surprise," which Weiskott takes at face value, requires qualification in regard to Old English. Surely members of the audience did not know which of the five basic rhythms a verse would display, but one thing they knew for certain: that of all the possible rhythmical sequences of their language, any verse would be limited to a subset of rhythms generated by the strict requirements of alliteration. Further, they also knew that some rhythms were allowed only in the on-verse, and that, regardless of its rhythm, a verse would conform to a regular and hence

\footnotetext{
${ }^{9}$ Verses like the hypothetical *folce tō helpe, with an expanded drop (-ce tō) and single alliteration, are not normal, whereas verses like Beowulf 14a, folce tō frōfre, with an expanded drop and double alliteration, are regular.
} 
predictable pattern of alliteration across the line. Therefore, despite their rhythmical variability, the verses of Old English poetry never came as a 'surprise' for members of the audience. The uncertainty about the specific rhythm of a verse (Weiskott's 'inductive scansion') can then be seen to be more than offset by the predictability brought about by alliteration. Consequently, alliteration is, in spite of Weiskott's opinion to the contrary, more essential to Old English poetry than the rhythmical variability of its verses. In fact, it is difficult to imagine how, in the face of its rhythmical variability, Old English versification could have preserved its integrity as a metrical system without the constraining function performed by alliteration. ${ }^{10}$

What would happen to Old English poetry if the requirements of alliteration were relaxed or if the alliterative scheme were removed? Since alliteration limits the possible rhythms, the rhythmical variability of each verse would increase dramatically, to the point that its pattern would become completely unpredictable. This is precisely the situation that we find in early Middle English poetry, a representative example of which is furnished by Lazamon's Brut. To be sure, the rhythmical and alliterative patterns of its lines sometimes resemble those of classical Old English verse, but other alliterative schemes - and hence also other rhythmical configurations - frequently occur. The relaxation of the alliterative scheme and its concomitant proliferation of rhythms were accompanied by the not infrequent use of rhyme as a linking device between verses, which also added to the rhythmical variability of the Brut. (Many of its rhyming verses consist of an almost regular alternation of stressed and unstressed syllables that make them sound like couplets.) Moreover, half-lines occasionally lack a formal link, which means that any syntactically coherent

\footnotetext{
${ }^{10}$ Weiskott seems to anticipate this objection when he says, "the regularity of the meter lies in the way that individual verses fulfill a set of independent minimum requirements” (2016: 10). One of these requirements in Old English verse is, according to him, the regulated placement of protracted drops within the half-line. In other words, alliteration has nothing to do with the metricality of a verse, which is rather predicated upon the systematic placement of its protracted drops either before the first lift in types B and C or immediately after it in type A. As seen above, however, the distribution of protracted drops within the verse is determined by the location of the alliterating lifts.
} 
group of words allowed by the language can potentially function as a verse. It is no wonder that Arthur Wayne Glowka, one of the most dedicated students of the style of the Brut, referred to this rhythmical heterogeneity as "prosodic disorder” (1984: 48). Thus, Weiskott's idea that the rhythms of alliterative verse are unpredictable is clearly true of early Middle English poems, whose lines could be anything ranging from a combination of two classical Old English half-lines to a rhyming couplet to a pair of natural syntactic units. Nevertheless, Weiskott's classification does not apply to Old English poetry, the rhythmical possibilities of whose verses are severely constrained by the line's alliterative scheme.

It can now be seen that Weiskott's classification of both Old and early Middle English poetry as inductive meters conceals a difference between the two that is crucial for understanding the history of the alliterative tradition. In Old English verse, only a limited number of rhythms can occur, and some of the most recurrent result from the accumulation of all the unstressed syllables of a half-line immediately before an alliterating lift. The correlation between groups of unstressed syllables and alliteration is so regular that it demands an explanation, and this is to be found in the prehistory of Old English. As the language that would eventually become Old English was evolving from a more synthetic to a more analytical status, its number of function words - and hence of unstressed syllables - considerably increased. Unstressed syllables threatened to dilute the rhythms of the poetry, and so a way was found to incorporate them without disrupting the structural integrity of their lines. It is unsurprising that this was achieved by gathering all the unstressed syllables of the verse immediately before one of its alliterating syllables. As is well known, alliteration in early Germanic verse exclusively falls on stressed syllables, which means that alliteration lends additional prominence to an already prominent prosodic entity, thereby increasing the dissimilarity between stressed and unstressed syllables. Alliterating syllables were 
made to stand out so prominently that they were able to cancel out the diluting effect of an immediately preceding series of unstressed syllables, thus allowing listeners to analyze it as a metrical constituent of the verse. ${ }^{11}$

There is, as can be seen, a close connection between alliteration, meter, and orality in Old English poetry. In order to enable listeners to scan series of unstressed syllables, poets placed them immediately before alliterating lifts, thereby generating the metrical configurations of the verses. The connection of alliteration to meter and real-time scansion becomes particularly noticeable in its role in determining the metrical behavior of finite verbs. On account of their intermediate prosodic status, finite verbs are allowed to evince an ambiguous behavior in the first half of the line. In Beowulf, for example, we find on-verses like 2542a, Geseah ðā bē wealle, ${ }^{12}$ 2756a, Geseah ðā sigehrēðig, ${ }^{13}$ and 2767a, Swylce he siomian $\dot{g} e s e a h,{ }^{14}$ in which the finite verb $\dot{g} e s e a h$ respectively is non-alliterating and non-ictic, alliterating and non-ictic, and alliterating and ictic. At the beginning of the off-verse, however, if a finite verb is able to participate in the alliteration of the line, then it must also bear metrical ictus. The implication is that verses like 2756a, with a finite verb with ornamental, non-ictic alliteration, are prohibited in the second half of the line. The rationale behind this stricture is that their scansional ambiguity would have been too great for members of the audience to bear. After the recitation of the on-verse, the line's pattern of alliteration was clear in the listeners' minds, and so they would have found it too difficult to disregard the alliteration on a finite verb as non-ictic (Pascual 2015: 176-179). In order to remove

\footnotetext{
${ }^{11}$ In this manner, the strategic accumulation of unstressed syllables before alliterating lifts gave rise to the protracted drop in Old English meter. It therefore played a fundamental role in the development of the four-position principle, which is predicated upon the ability of a single drop to accommodate an uninterrupted series of unstressed syllables. For an overview of the development of the four-position principle, see Fulk 1996: 68 and Pascual 2016. On the fundamental character of this rule for the composition of Old English verse, see Pascual 2013-2014 and 2017, and Neidorf 2016.

12 "[He] saw then in the wall."

13 "The victorious triumphant then saw."

14 "He also saw hanging."
} 
such scansional complexity, the metrical system relies on alliteration, the presence or absence of which determines the metrical value of a finite verb at the beginning of the off-verse.

The ultimate motivation behind the rules of alliterative meter thus appears to have been the facilitation of real-time scansion of the long line for members of an audience. To the rule-governed placement of unstressed syllables within the verse and the metrical behavior of finite verbs at the beginning of the second half-line, which have already been discussed, we might add the strict prohibition against the second lift of the off-verse to alliterate, which furnished a clear aural boundary between one line and the next. The oral nature of alliterative meter has important implications for literary history. The goal of the orchestrated interaction of the metrical rules was to enable the oral delivery of the poetry to a community of listeners who shared the same expectations about the meter. This means that traditional poets had to compose according to the rules of a coherent metrical system, since failure to do so would have resulted in poetic material that, on account of its heterogeneity, would not have met the metrical expectations of the audience. In this light, how is the "prosodic disorder" of early Middle English verse to be interpreted? As seen above, its rhythmical heterogeneity is so high that the patterns of its lines would have been unpredictable to a hypothetical audience. There is, in fact, no integral set of metrical rules that could have generated the unchecked variability of early Middle English poems, which do not seem to have been composed with the metrical expectations of an audience in mind. It appears reasonable to conclude, therefore, that Lazamon and his contemporaries were not poets within the alliterative tradition, as Weiskott would have us believe. Their styles look like an eclectic, nontraditional combination of classical and innovative features, ${ }^{15}$ and so these poets are better conceptualized as literate experimenters who took advantage of their alienation from the rigid

\footnotetext{
${ }^{15}$ For a similar characterization of Lazamon's style, see Donoghue 1990: 543.
} 
constraints of an oral meter in order to develop new rhythms and use foreign forms, like the rhyming couplets, as a structural principle in their works.

Does this mean that, as a result of the considerable changes that the language underwent, Old English meter disintegrated at the end of the Anglo-Saxon period, thereby giving rise to the idiosyncrasies of early Middle English poets? The evidence suggests not. As mentioned above, the high incidence of Old English-derived poeticisms in fourteenth-century alliterative verse indicates that the classical alliterative tradition survived the political demise of the Anglo-Saxons in 1066. This is corroborated not only by the systematic reliance of both Old English and late Middle English poets on the same alliterative scheme for binding their verses together, but also by the strict constraints that late Middle English versification imposes upon the rhythmical variability of the off-verse. As is well known, the second half-line in poems of the Alliterative Revival must consist of no more and no less than one protracted drop, which must occur either immediately before or after the first, alliterating lift (Cable 1988, Duggan 1988). This metrical rule, whose effect is to restrict the number of rhythms that can occur in the second half-line, is best explained as the result of the efforts of traditional poets to preserve the structural integrity of the alliterative long line at a time of linguistic change.

Like their prehistoric peers, poets at the end of the Anglo-Saxon period had to deal with a significant increase in the number of function words in their language - except that this time the incidence of such words was already relatively high. Consequently, although poets were still able to generate classical verses by placing many of these function words in their traditional location within protracted drops, they must have found it unavoidable to compose verses with new, nontraditional rhythmical patterns. The emergence of these new rhythms posed a serious threat to the structural integrity of the alliterative long line, but the poets managed to cope with it by adopting 
a very traditional strategy. Classical rhythmical sequences with one protracted drop, which had until then been permitted to occur in either half of the line, ${ }^{16}$ were systematically moved to the second half. This allowed poets to accommodate all the new rhythms in the first half, which is the part of the line where listeners had traditionally expected the presence of ambiguous and complicated material (Russom 2004, Fulk 2004: 307-308). Thus, the basic metrical rule of late Middle English versification, according to which an off-verse must contain exactly one protracted drop either before or after the first lift, arose as the poets sought to keep the alliterative long line recognizable for members of the audience. To be sure, the Old English stricture against the placement of protracted drops before non-alliterating lifts ceased to be observed, but this loss was offset by a reduction in the number of rhythms that the second half-line tolerates.

\section{Conclusion}

The long line, understood as a regular and hence predictable pattern of alliteration across a caesura, thus emerges as the most essential feature of English alliterative verse. The complex systems of metrical rules that modern scholars inductively derive from Old and late Middle English verse texts were simply the most natural ways for poets of the two periods to facilitate the real-time scansion of the alliterative long line for their audiences. Alliteration, therefore, can be said to generate the meter. ${ }^{17}$ The same holds true for the entire Germanic poetic tradition: from the early fifth-century runic inscription on the Golden Horn of Gallehus to Sir Gawain and the Green Knight, and from the Northern poetic edda to the Southern Hildebrandslied, all alliterative poetry is characterized by the same alliterative patterning, and so the long line, with its regular and

\footnotetext{
${ }^{16}$ This is true of type B and C verses with an expanded initial drop. Type A verses with a protracted drop feature double alliteration, and so they occur only in the on-verse.

${ }^{17}$ It can also be said to generate the verse syntax. Kuhn's first law demands that, if a particle is to be non-ictic, it must occur in the first drop of the clause. This verse-syntactic regularity probably arose as the poets were accumulating all the elements of relatively low prosodic status before alliterating lifts. The syntactic constituents of poetic clauses thus appear to be organized on an alliterative basis. See Fulk, Bjork, \& Niles 2008: cxvii, n.4. Dependable accounts of Kuhn's first law can found in Donoghue 1987: 7-8 and Momma 1997: 56-64.
} 
predictable alliterative scheme, is to be considered the most permanent and defining feature of alliterative verse. Weiskott's classification of alliteration as an inessential feature of this verse can thus be seen to be nothing more than a tendentious attempt at including early Middle English poetry in the alliterative tradition. As seen above, however, Lazamon and his contemporaries did not consistently structure their lines around alliteration, and so their connection to the alliterative tradition can only be considered tangential. There can be little doubt that their compositions do not reflect the strict metrical practices that the preservation of the alliterative long line demanded at a time of drastic linguistic change.

The ultimate source of Weiskott's error is his bias against the philological theory that the tradition of alliterative verse flourished for a period of approximately two hundred and fifty years in ways that are not captured by written survivals. This essay has demonstrated that there is nothing inherently improbable about that theory. A detailed examination of the role of alliteration has shown that the rules of the meter make the alliterative pattern of the long line recognizable to a community of listeners. These rules ensured the successful oral transmission of alliterative poetry for many centuries before its practitioners came into contact with literacy, and continued to ensure it even during the Anglo-Saxon period, when most of the poetry that was orally composed was never written down. It is, therefore, only natural to suppose that the oral transmission of alliterative verse was likewise guaranteed by the rules of the meter between the end of the Anglo-Saxon period and the Alliterative Revival. ${ }^{18}$ The resistance against the theory of oral transmission is little more than a byproduct of modern lack of exposure to oral literature. If one aim of metrical scholarship

\footnotetext{
${ }^{18}$ Moreover, scholars of related literary traditions naturally rely on the assumption of oral poetic transmission in order to construct their literary histories. Ramón Menéndez Pidal, the preeminent Spanish philologist, compellingly demonstrated the existence of analogues of Germanic legends in the old balladry of Spain. On the basis of this and other important pieces of evidence, Hispanic philologists account for the medieval Spanish epic tradition (the most illustrative representative of which is the Cantar de Mío Cid) as an outgrowth of the oral body of Germanic heroic poetry that the Visigoths carried with them to the Iberian Peninsula in the fifth century. See, for example, Menéndez Pidal 1969 and Bravo García 1977-1978.
} 
is to understand the development of alliterative verse, modern scholars will do well to repress such presentist impulses before they commit their thoughts to writing.

\section{REFERENCES}

Blake, Norman. 1969. Rhythmical alliteration. Modern Philology 67, 118-124.

Bravo García, A. 1977-1978. Elfa: Un elemento germánico en el Mío Cid. Archivum 27-28, 181190.

Cable, Thomas. 1988. Middle English meter and its theoretical implications. The Yearbook of Langland Studies 2, 47-69.

Cole, Lynn. 2007. Rum, ram, ruf, and rym: Middle English alliterative meters. Ph.D. dissertation, The University of Texas at Austin.

Donoghue, Daniel. 1987. Style in Old English poetry: The test of the auxiliary. New Haven: Yale University Press.

Donoghue, Daniel. 1990. Lazamon’s ambivalence. Speculum 65, 537-563.

Duggan, Hoyt N. 1986. Alliterative patterning as a basis for emendation in Middle English alliterative poetry. Studies in the Age of Chaucer 8, 73-105.

Duggan, Hoyt N. 1988. Final $-e$ and the rhythmic structure of the b-verse in Middle English alliterative poetry. Modern Philology 86, 119-145.

Duncan, Edwin. 1993. Weak stress and poetic constraints in Old English verse. The Journal of English and Germanic Philology 92, 495-508.

Everett, Dorothy. 1955. Essays on Middle English, rev. ed. by Patricia Kean. Oxford: Clarendon.

Fulk, R.D. 1996. Rhetoric, form, and linguistic structure in early Germanic verse: Toward a synthesis. Interdisciplinary Journal for Germanic Linguistics and Semiotic Analysis 1, 63-88. 
Fulk, R.D. 2004. Old English poetry and the alliterative revival: On Geoffrey Russom's “The evolution of Middle English alliterative meter.” In Anne Curzan \& Kimberly Emmons (eds.), Studies in the history of the English language II: Unfolding conversations, 305-312. Berlin: Mouton de Gruyter.

Fulk, R.D. (ed. and trans.). 2010. The Beowulf manuscript: Complete texts and The Fight at Finnsburg. Cambridge, MA: Harvard University Press.

Fulk, R.D. 2012. An introduction to Middle English: Grammar and texts. Peterborough, Ont.: Broadview Press.

Fulk, R.D., Robert E. Bjork, \& John D. Niles (eds.). 2008. Klaeber's Beowulf: Fourth edition. Toronto: University of Toronto Press.

Glowka, Arthur Wayne. 1984. Prosodic decorum in Layamon’s Brut. Poetica 18, 40-53.

Menéndez Pidal, Ramón. 1969. Los godos y la epopeya española: “Chansons de geste” y baladas nórdicas, $2^{\text {nd }}$ ed. Madrid: Espasa Calpe.

Momma, Haruko. 1997. The composition of Old English poetry. Cambridge: Cambridge University Press.

Neidorf, Leonard. 2016. Metrical criteria for the emendation of Old English poetic texts. In Leonard Neidorf, Rafael J. Pascual, \& Tom Shippey (eds.), Old English philology: Studies in honour of R.D. Fulk, 52-68. Cambridge: D.S. Brewer.

Oakden, J. P. 1930-1935. Alliterative poetry in Middle English, 2 vols. Manchester: Manchester University Press.

Pascual, Rafael J. 2013-2014. Three-position verses and the metrical practice of the Beowulf poet. SELIM 20, 49-79. 
Pascual, Rafael J. 2014. Elfric’s rhythmical prose and the study of Old English metre. English Studies 98, 803-823.

Pascual, Rafael J. 2015. On a crux in Beowulf: The alliteration of finite verbs and the scribal understanding of metre. Studia Neophilologica 87, 171-185.

Pascual, Rafael J. 2016. Old English metrical history and the composition of Widsið. Neophilologus 100, 289-302.

Pascual, Rafael J. 2017. Manuscript evidence and metrical authenticity: A response to Seiichi Suzuki. Journal of Germanic Linguistics 29, 85-99.

Russom, Geoffrey. 2004. The evolution of Middle English alliterative meter. In Anne Curzan \& Kimberly Emmons (eds.), Studies in the history of the English language II: Unfolding conversations, 279-304. Berlin: Mouton de Gruyter.

Tolkien, J.R.R. \& E.V. Gordon (eds.). 1967. Sir Gawain and the Green Knight, $2^{\text {nd }}$ ed. rev. by Norman Davis. Oxford: Clarendon.

Weiskott, Eric. 2016. English alliterative verse: Poetic tradition and literary history. Cambridge: Cambridge University Press.

Yakovlev, Nicolay. 2008. The development of alliterative metre from Old to Middle English. Ph.D. dissertation, University of Oxford. 